\title{
EPIDEMIOLOGY
}

\section{Exercise in leisure time: coronary attack and death}

\author{
rates
}

\author{
J N Morris, D G Clayton, M G Everitt, A M Semmence, E H Burgess
}

Department of Public Health and Policy, London School of Hygiene and Tropical Medicine, London $\mathrm{J} N$ Morris M G Everitt

Department of Community Health, University of Leicester D G Clayton

Civil Service Occupational Health Service

A M Semmence

E H Burgess

Correspondence to

Professor J N Morris, Department of Public Health and Policy, London School of Hygiene and Tropical of Hygiene and Tropical London WC1E 7HT.

Accepted for publication 20 December 1989

\begin{abstract}
Nine thousand three hundred and seventy six male civil servants, aged 45-64 at entry, with no clinical history of coronary heart disease, were followed for a mean period of 9 years and 4 months during which 474 experienced a coronary attack. The $9 \%$ of men who reported that they often participated in vigorous sports or did considerable amounts of cycling or rated the pace of their regular walking as fast (over 4 $\mathrm{mph}, 6.4 \mathrm{~km} / \mathrm{h}$ ) experienced less than half the non-fatal and fatal coronary heart disease of the other men. In addition, entrants aged 55-64 who reported the next lower degree of this vigorous aerobic exercise had rates less than two thirds of the remainder; entrants of 4554 did not show such an effect. When these forms of exercise were not vigorous they were no protection against the disease, nor were other forms of exercise or high totals of physical activity per se. A history of vigorous sports in the past was not protective. Indications in these men are of protection by specific exercise: vigorous, aerobic, with a threshold of intensity for benefit and "dose response" above this threshold, exercise that has to be habitual, and continuing, which suggests that protection is against the acute phases of the disease. Those men who took vigorous aerobic exercise were demonstrably a favourably "selected" group; they suffered less of the disease, however, whether at low risk or high by the several risk factors that were studied. Men with exercise-related reduction in coronary heart disease also had lower death rates from the total of other causes, and so lower total death rates than the rest of the men.
\end{abstract}

Initial observation that middle aged men in jobs that require physical activity have a lower incidence of heart attack than comparable men in sedentary jobs ${ }^{1}$ prompted the hypothesis that high totals of physical activity in leisure time would protect sedentary workers. ${ }^{2}$ Prospective survey of such men in the civil service, however, did not corroborate this. Only those reporting vigorous aerobic exercise showed substantially less coronary heart disease.
Vigorous exercise included the most strenuous activities of these men, so it was well above their normal levels of activity, and it was further defined as being liable to entail peaks of energy expenditure of $7.5 \mathrm{kcal} / \mathrm{min}$, $31.5 \mathrm{~kJ} / \mathrm{min}$ (say $>6.0$ resting equivalents (METS) and $>65 \%$ of maximum oxygen uptake). This is usually adequate, it may be postulated, to produce and maintain a cardiorespiratory training effect in such a population. ${ }^{3-8}$

It is hazardous, however, to generate a new hypothesis post hoc from the same data set. Furthermore, in an admittedly different population of American men, though players of vigorous sports showed the lowest coronary rates, there was some protection also in a minority who took less intense aerobic exercise, and thus had high totals of leisure activity ( $\geqslant 2000 \mathrm{kcal}$ per week) ${ }^{10}$ (and Paffenbarger et al, 1988, personal communication). As well as questions about the kind of exercise that is protective against heart disease, of a postulated threshold for benefit and, in general, how to represent physiological "training" in a population study, many other issues must be considered. These are: the effects of advancing age; the possibility of other causes of death occurring among those protected, or being diagnosed instead; the interaction of exercise with other behaviours, and with standard risk factors; the multiplicity of possible mechanisms for the protection now being proffered-and the abiding question of possible self selection for exercise and against heart attack. In the hope of shedding further light on such issues a prospective survey was launched.

\section{Subjects and methods}

In the autumn of 1976 all male executive officers aged 45-64 in post in the Department of Health and Social Security and in Inland Revenue throughout Britain were invited to participate. These officers are (or were) a white collar middle management grade, a narrow though not untypical, homogeneous and stable educational/occupational/economic band of the middle class, engaged in sedentary or physically light office work. Eighty two per cent of the men readily agreed, yielding 9376 respondents after exclusion of the $6 \%$ with a history or record of clinical coronary heart disease. They constitute the study cohort who 
were followed until 30 April 1986. They were asked to give a detailed account of physical activity in the previous 4 weeks in a questionnaire designed (after pilot interviews) to be comparable with the national data of the General Household Survey ${ }^{112}$ (and personal communication, OPCS, 1979). The intensity and energy demands of the activities reported were derived as best we could from physiological studies 3481314 to provide the broad gradings required.

A $25 \%$ random sample of the completed questionnaires was drawn, coded independently and in full by two clerical officers, and checked and reconciled, as occasionally required, by $M G E$; this sample was multiplied by four to estimate our total population data.

As before ${ }^{34}$ the Occupational Health Service of the Civil Service reported, in confidence, major morbidity among all men (episodes of sickness absence over 30 days in one year or within two consecutive years, with their certified cause; and episodes of any duration certified as cardiovascular disease) together with the man's medical history. The diagnoses thus were derived from information provided by the men, by the men's general practitioners, and by weekly certificates from National Health Service hospitals. In a few instances where no categorical diagnosis had been made, we ourselves checked with the doctors and hospitals for the clinical details. There were also a small number of retirements on medical grounds. These men normally retire at 60 , so we disregarded morbidity after 60 . All this yielded 202 non-fatal cases during the follow up: these were the first recognised clinical episodes of coronary heart disease in men aged 45-59; in most these were "coronary thrombosis/acute myocardial infarction" with a few cases of angina pectoris or coronary insufficiency.

Deaths were notified by the departments and the Paymaster General; all men in the survey were also flagged at the National Health Service Central Registry which routinely sent copies of death certificates. All these were processed by the Medical Division of the Office of Population Censuses and Surveys and those classified as coronary heart disease (ICD 410 414) as the main or underlying cause of death (plus two deaths overseas) in men not already accepted as cases of coronary morbidity were admitted as 272 fatal cases. These were spread through the cohort aged 45-64, observed prospectively for 9.3 years; the highest age at death was 73 years.

These deaths together with the non-fatal cases, 474 in all, in 87563 man-years' observation (44 933 at $45-59$ and 42630 at $60-73$ ) make up our composite age standardised coronary attack rate of 5.41 per 1000 manyears, with the non-fatal cases being aged 4559 at the event and the fatal 45-73. In the analysis of mortality it seemed more rigorous to include all coronary deaths during the observed follow up. This added 17 deaths in second or later episodes to the 272 , too few though to make a material difference.

The questionnaires of all the cases were coded in the same way as the cohort sample.

This therefore is a case-cohort study ${ }^{15}$ permitting estimation of man-years observed and the calculation of population rates, not merely individual relative risks (see Appendix).

\section{PHYSICAL ACTIVITY IN LEISURE TIME}

This takes three forms in these men: (a) sports and games, keep fit/callisthenics; $(b)$ moving about-walking, cycling, stair climbing; $(c)$ manual work in and about the house and garden and on the car-that is "work" in the general sense not the physiological term.

Previously, a cluster of frequent/"vigorous" (as defined) aerobic, dynamic exercise in (a) and $(b)$ was associated with much lower coronary incidence rates (first clinical episodes). This became the main hypothesis to be tested. At the same time, the five components of the cluster-vigorous sports, daily or near daily keep fit, fast walking, considerable amounts of cycling, the extreme of stair climbing-were tested individually. More tentatively, we tested the hypotheses that much vigorous manual work, which previously had shown a limited association with incidence, would also provide some protection and that other physical activity would not be protective.

\section{Results}

EXERCISE AND RATES OF CORONARY HEART DISEASE Sports and games

Table 1 breaks these down into "vigorous",

Table 1 Playing of sports and games and the attack rate of coronary heart disease in male executive grade civil servants (rates per 1000 man-years)

\begin{tabular}{|c|c|c|c|c|c|c|}
\hline \multirow{3}{*}{$\begin{array}{l}\text { Episodes in previous } 4 \text { weeks } \\
\text { reported at entry in } 1976\end{array}$} & \multicolumn{3}{|c|}{ (A) Vigorous sports ${ }^{\star}$} & \multicolumn{3}{|c|}{ (B) Non vigoroust } \\
\hline & \multicolumn{3}{|c|}{ Coronary attacks (1976-86) } & \multicolumn{3}{|c|}{ Coronary attacks (1976-86) } \\
\hline & Cases & Man-years & Age standardised rate & Cases & Man-years & Age standardised rate \\
\hline \multirow{2}{*}{$\begin{array}{l}\text { None } \\
1-3 \\
4-7 \\
8-11 \\
\geqslant 12\end{array}$} & $\begin{array}{r}413 \\
37 \\
17\end{array}$ & $\begin{array}{r}72282 \\
7786 \\
4146\end{array}$ & $\begin{array}{l}5 \cdot 8 \\
4 \cdot 5 \\
4 \cdot 1\end{array}$ & \multirow{2}{*}{$\begin{array}{r}310 \\
85 \\
52 \\
19 \\
8\end{array}$} & \multirow{2}{*}{$\begin{array}{r}58326 \\
14190 \\
8532 \\
5322 \\
1193\end{array}$} & \multirow{2}{*}{$\begin{array}{l}5.4 \\
5.9 \\
5.9 \\
3.5 \\
6.8\end{array}$} \\
\hline & 7 & 3349 & $2 \cdot 1$ & & & \\
\hline Total & \multicolumn{2}{|c|}{$p<0.005$} & $5 \cdot 4$ & \multicolumn{2}{|c|}{$p>0.05$} & \\
\hline
\end{tabular}

Men aged 45-64 at entry in 1976 with no history or record of coronary heart disease followed to 1986 . Attack rates include all recognised first coronary events, nonfatal ( 202 at $45-59$ years) and fatal ( 272 at $45-73$ years of age).

*Liable to reach energy output of $7.5 \mathrm{kcal}(31.5 \mathrm{~kJ})$ per minute.

†Results were similar when men also reporting vigorous sports are excluded.

All significance tests reported are for trend, ${ }^{16}$ although heterogeneity tests were also carried out, and allow for sampling of the population (see Appendix).

The few men with no or spoiled records are included in None. 
reported by $17 \cdot 5 \%$ of the men, and "nonvigorous" sports, which were twice as common. The contrast between $(A)$ and $(B)$ is plain, corroborating the hypothesis of a threshold of intensity for effectual exercise. There is some indication too in (A) of a "dose response" with frequency; the finding with $\mathbf{8}$ or more episodes of exercise-that is at least twice a week on average-reported by $3.8 \%$ of the men, is the strict test of the hypothesis.

Swimming was the most popular vigorous sport; there were also appreciable numbers of men jogging, playing badminton, tennis, football, and hockey (including coaching and refereeing), hill climbing, and rowing. Dancing, golf, and table tennis were the commonest non-vigorous sports.

Validity: intensity of exercise. We asked participants about symptoms induced by activity to see whether exercise classed as "vigorous aerobic" by our simple methods did indeed demand greater exertion. These data and the many issues they raise will be reported elsewhere. But we certainly found that the men reported being "out of breath" more often with sports that we deemed to be vigorous.

Previous history of exercise. Participants were asked whether they had played vigorous sports and stopped before entry to the survey. Men who reported such sports at entry in 1976 often replied that they had engaged also in other such sports in the past, illustrating "self-selection" for vigorous exercise. More interestingly, in men reporting no vigorous sports in 1976 there was no relation between coronary attacks during the follow up, 1976-86, and earlier playing of vigorous sports:

Vigorous sports previously played by men reporting none in 1976:

\begin{tabular}{lrr} 
& \multicolumn{2}{c}{$1976-86$} \\
Played none previously & 292 & $5 \cdot 9$ \\
Played up to 25 years of age & 42 & $5 \cdot 1$ \\
Played up to 30 years of age & 33 & $5 \cdot 1$ \\
Played up to 40 years of age & 36 & $6 \cdot 5$ \\
Played past 40 years of age & 8 & $5 \cdot 2$
\end{tabular}

The results are the same even if only the most vigorous sports are considered-athletics, rugby, running, squash, boxing, and the like. The implication is that continuing current exercise alone protects against the disease. This independently corroborates and amplifies the American observation. ${ }^{9}$ The observation argues, too, against a critical genetic component in the exercise effect.

Consistency in behaviour pattern. The hypothesis implies that the protective behaviour is habitual. Vigorous aerobic exercise was found to be a particularly stable trait in the short term and when we compared reports in the present survey with those in the first. ${ }^{34}$ There is a further confirmation from a follow up performed for us by the Paymaster General in 198284 of the $40 \%$ of our participants aged 55-64 who had by then retired; $92 \%$ of them responded. Each man reporting vigorous sports in 1976 was matched randomly by age, smoking, and length of follow up with three controls who in 1976 had reported no such activities. Half $(51 \%)$ of the former reported vigorous sports again in 1982-84 and a further $19 \%$ reported other vigorous aerobic exercise, mainly keep fit. The proportions in the controls were $13 \%$ and $9.5 \%$ respectively.

\section{MOVING ABOUT}

We asked the men for information on how many minutes they had spent walking to and from work and on other regular walking outside the home in the past week. The quantity of walking (table 2A) was not associated with any decline in attack rates-for example, the figure of 6.0 with average walking of over an hour a day. Participants were also asked to grade the usual or average pace or speed of their regular walking. ${ }^{1718}$ To test the threshold hypothesis, "fast" was defined as "over $4 \mathrm{mph}$ " $(6.4 \mathrm{~km} / \mathrm{h})$. Table 2B shows a trend in the rates of disease and there is a particularly low rate in the $2.6 \%$ of men claiming to be fast walkers. In table $2 \mathrm{C}$, combining intensity and quantity, there is a somewhat reduced attack rate in those reporting over half an hour a day of "fairly brisk" walking. This, which is the grade below "fast" walking and perceived to be faster than "normal", is deliberately strenuous, it may be postulated, vigorous, and the rate may be another indication of a dose response. The "strollers", $11 \%$ of the men, reported many mobility problems, and they were generally

Table 2 Regular walking ${ }^{\star}$ and the attack rate of coronary heart disease (1976-86) in male executive grade civil servants (rates per 1000 man-years)

\begin{tabular}{|c|c|c|c|c|c|c|c|c|c|c|c|c|c|c|}
\hline \multicolumn{3}{|l|}{ (A) Duration } & \multicolumn{3}{|l|}{ (B) Pace } & \multicolumn{9}{|c|}{ (C) Duration and pace } \\
\hline \multirow{2}{*}{$\begin{array}{l}\text { Hours of } \\
\text { regular walking } \\
\text { in past week }\end{array}$} & \multicolumn{2}{|c|}{ Coronary attacks } & \multirow{2}{*}{$\begin{array}{l}\text { Usual } \\
\text { average } \\
\text { pace† }\end{array}$} & \multicolumn{2}{|c|}{ Coronary attacks } & \multirow{2}{*}{$\begin{array}{l}\text { Hours } \\
\text { in past } \\
\text { week }\end{array}$} & \multicolumn{2}{|l|}{ Stroll } & \multicolumn{2}{|c|}{ Normal } & \multicolumn{2}{|c|}{ Fairly brisk } & \multicolumn{2}{|l|}{ Fast } \\
\hline & Cases & Rates & & Cases & $\overline{\text { Rates }}$ & & Cases & $\overline{\text { Rates }}$ & Cases & Rates & Cases & Rates & Cases & $\overline{\text { Rates }}$ \\
\hline Noneł & 51 & $5 \cdot 0$ & $\begin{array}{l}\text { "Stroll } \\
\text { at an easy } \\
\text { pace" }\end{array}$ & 78 & 7.9 & & & & & & & & & \\
\hline $\begin{array}{l}3 \cdot 5 \\
7\end{array}$ & $\begin{array}{r}317 \\
85\end{array}$ & $\begin{array}{l}5 \cdot 6 \\
5 \cdot 1\end{array}$ & $\begin{array}{l}\text { "Normal" } \\
\text { "Fairly } \\
\text { brisk". }\end{array}$ & $\begin{array}{l}222 \\
120\end{array}$ & $\begin{array}{l}5 \cdot 5 \\
4 \cdot 8\end{array}$ & $\begin{array}{l}\leqslant 3.5 \\
>3.5\end{array}$ & $\begin{array}{l}64 \\
14\end{array}$ & $\begin{array}{r}7 \cdot 3 \\
12 \cdot 0\end{array}$ & $\begin{array}{r}163 \\
59\end{array}$ & $\begin{array}{l}5 \cdot 2 \\
6.9\end{array}$ & $\begin{array}{l}88 \\
32\end{array}$ & $\begin{array}{l}5 \cdot 7 \\
3 \cdot 4\end{array}$ & $\begin{array}{l}2 \\
1\end{array}$ & $\begin{array}{l}(1.5) \\
(0.9)\end{array}$ \\
\hline 7 & 21 & $6 \cdot 0$ & $\begin{array}{l}\text { (Fast } \\
4 \mathrm{mph} \text { )" }\end{array}$ & 3 & $(1 \cdot 3)$ & & & & & & & & & \\
\hline Total & $\begin{array}{l}474 \\
p>0.05\end{array}$ & & $p<0.05$ & & & & . & & & & & & & \\
\hline
\end{tabular}


Table 3 Recreational "work" and the attack rate of coronary heart disease (1976-86) in male executive grade civil servants (rates per 1000 man-years)

\begin{tabular}{|c|c|c|c|c|c|c|c|c|c|c|c|c|}
\hline \multirow{3}{*}{$\begin{array}{l}\text { Hours in previous } \\
4 \text { weeks } \dagger\end{array}$} & \multicolumn{4}{|c|}{ (A) Heavy work ${ }^{\star}$} & \multicolumn{4}{|c|}{ (B) Moderate } & \multicolumn{4}{|c|}{ (C) Light } \\
\hline & \multicolumn{2}{|c|}{ Gardening } & \multicolumn{2}{|l|}{ Other } & \multicolumn{2}{|c|}{ Gardening } & \multicolumn{2}{|l|}{ Other } & \multicolumn{2}{|c|}{ Gardening } & \multicolumn{2}{|l|}{ Other } \\
\hline & Cases & Rates & Cases & Rates & Cases & Rates & Cases & Rates & Cases & Rates & Cases & Rates \\
\hline $\begin{array}{l}\text { None } \\
1-3 \\
4-7 \\
8-11 \\
\geqslant 12 \\
\text { Total }\end{array}$ & $\begin{array}{r}227 \\
175 \\
42 \\
15 \\
15 \\
474\end{array}$ & $\begin{array}{l}5 \cdot 7 \\
5 \cdot 4 \\
4 \cdot 9 \\
5 \cdot 4 \\
4 \cdot 3\end{array}$ & $\begin{array}{r}253 \\
155 \\
21 \\
29 \\
16 \\
474\end{array}$ & $\begin{array}{l}5 \cdot 3 \\
5 \cdot 7 \\
4 \cdot 6 \\
5 \cdot 3 \\
5 \cdot 9\end{array}$ & $\begin{array}{r}179 \\
261 \\
30 \\
4 \\
0\end{array}$ & $\begin{array}{c}5.2 \\
5.6 \\
5 \cdot 2 \\
(5 \cdot 4) \\
0\end{array}$ & $\begin{array}{r}123 \\
213 \\
50 \\
51 \\
37\end{array}$ & $\begin{array}{l}4 \cdot 9 \\
5.5 \\
5 \cdot 3 \\
5.7 \\
6.5\end{array}$ & $\begin{array}{r}213 \\
206 \\
38 \\
8 \\
9\end{array}$ & $\begin{array}{l}5.7 \\
5 \cdot 1 \\
5.8 \\
4.2 \\
5 \cdot 2\end{array}$ & $\begin{array}{r}119 \\
265 \\
44 \\
31 \\
15\end{array}$ & $\begin{array}{l}5.1 \\
5.2 \\
6.7 \\
6.9 \\
5.9\end{array}$ \\
\hline
\end{tabular}

*Liable to reach energy output of $7.5 \mathrm{kcal}(31.5 \mathrm{~kJ})$ per minute.

+ Reported at entry.

$p>0.05$ throughout.

vulnerable (for example $15 \%$ of them gave a history of "subclinical" cardiovascular disease); this simple self-assessment is remarkedly predictive of heart attack.

"Vigorous" cycling was defined as an amount previously found to be associated with a lower incidence: at least an hour per week in the round trip to work or at least 25 miles of other cycling in the previous week. Cyclists of course often reported both forms. In the $3.5 \%$ of men who reported vigorous cycling the attack rate was much lower: eight cases, 2.6 per 1000 manyears. There was also some reduction with less cycling: 14 cases and 4.5 per 1000 man-years ( $p$ $<0.03$ ), indicating perhaps that any habitual cycling in these middle aged men usually entailed enough effort for benefit. ${ }^{19}$ But as only $7 \%$ of the men cycled numbers are too few for proper analysis.

\section{KEEP FIT AND STAIR CLIMBING}

There was no association with age-standardised coronary rates in these two remaining types of vigorous aerobic exercise which previously were found to be protective. The attack rate with keep fit/callisthenics at least 5 times a week was 5.6 per 1000 man-years. Men climbing the most stairs ( $\geqslant 500$ each day) had an attack rate of 5.4 , which was in the middle of the observed range of rates (4.7 to $6 \cdot 2$ per thousand man-years) by total number of stairs that were climbed.

\section{RECREATIONAL "WORK"}

Most of these men lived in a suburban house with a garden: $91 \%$ reported gardening, Do It Yourself also was very popular, and a wide range of "jobs", hobbies, and crafts were reported. Table 3 divides this productive activity into gardening and the rest. It begins (A) with the most arduous work, that is "vigorous" as defined (as liable to entail an energy output of $7.5 \mathrm{kcal} / \mathrm{min}$ )-for example, digging, tree felling, concreting, and replacing worn parts of the car. Seventy per cent of men reported doing some of this type of work. "Moderate" work, approximately 5 but $<7.5$ $\mathrm{kcal} / \mathrm{min}$, was mostly lawn mowing by hand or painting and decorating, and polishing the car; $71 \%$ reported doing moderate work. "Light" jobs (C)-for example raking and pruning, and repair of home appliances-were equally popular. Table 3 shows that whatever the quantity or intensity of recreational work it had no effect on the rates of coronary heart disease.
THRESHOLD: DOSE RESPONSE

The men were now ordered by the exercise they reported, and in terms of the main hypothesis (table 4).

Group 1 consists of those reporting frequent/ intense, vigorous aerobic exercise-that is, vigorous sports at least twice a week, and/or "fast" walking, and/or considerable cycling.

Group 2 are the men reporting the next lower degree of such exercise which was either not so frequent (that is, vigorous sports at least once but less than twice a week, and/or less cycling) or not so intense (that is "fairly brisk" walking for over half an hour a day).

Group 3 was made up of those men taking residual vigorous aerobic exercise-that is, occasional sports (1-3 episodes in the 4 weeks), or shorter "fairly brisk" walking.

Group 4 are the men reporting no vigorous aerobic exercise.

The upper panel of table 4 shows the trends in coronary disease across groups $1-4$ for overall attacks and mortality (and similarly in the non-fatal cases, by subtracting "mortality" from "total attack rate"). Group 1 men had strikingly low rates throughout $(p<0.001)$.

In those who were 45-54 at entry, the composite group 2 rate was not reduced and not significantly different from that in groups 3 and 4 , while among entrants of 55-64, the men in group $2(19 \%)$ had a significantly lower rate of disease than groups 3 and $4(p \simeq 0.01)$. Equally interesting, the two items of the original "vigorous aerobic" cluster that did not qualify for group 1 (frequent keep fit and much stair climbing) were now associated with reduced coronary rates of 2.7 and 3.5 per 1000 man-years in these older men, and they have therefore been included with group 2; both activities are likely to be more variable and liable to be less intense on average than the exercise in group 1 . In group 3 there was some continuation of a favourable trend in rates in the older men. These therefore showed a dose response to the intensity of vigorous aerobic exercise. A threshold effect alone is seen in the younger men.

Validity of the diagnosis of coronary heart disease. As a check the 135 fatal cases certified by a coroner (medical examiner) after necropsy as coronary heart disease were sorted into the four exercise groups. The trend of the age standardised rates (45-64) for these cases is similar to the experience overall: $0.39,1.4,1.7$, 1.7 in groups $1-4$ respectively ( $<0.001$ ). 
Table 4 Vigorous aerobic exercise, attack rate, and mortality of coronary heart disease (CHD) (1976-86) in male executive grade civil servants (rates per 1000 man-years)

\begin{tabular}{|c|c|c|c|c|c|c|}
\hline $\begin{array}{l}\text { CHD experience } \\
1976-1986\end{array}$ & $\begin{array}{l}\text { Group } 1 \\
\text { (frequent vigorous aerobic } \\
\text { exercise) }\end{array}$ & $\begin{array}{l}\text { Group } 2 \\
\text { (next lesser } \\
\text { degree of this) }\end{array}$ & $\begin{array}{l}\text { Group } 3 \\
\text { (residual vigorous } \\
\text { aerobic exercise) }\end{array}$ & $\begin{array}{l}\text { Group } 4 \\
\text { (no vigorous } \\
\text { aerobic exercise) }\end{array}$ & Totals & $p$ \\
\hline \multicolumn{7}{|c|}{ Ages 45-64 at entry } \\
\hline $\begin{array}{l}\text { Attack rate: } \\
\text { Man-years observation } \\
\text { Cases } \\
\text { Rates } \\
\text { Relative risk }{ }^{\circ} \\
\left(95^{\circ}{ }_{0} \mathrm{CI}\right)\end{array}$ & $\begin{array}{l}8062 \\
18 \\
2 \cdot 2 \\
35 \\
(21-57)\end{array}$ & $\begin{array}{l}13185 \\
62 \\
4 \cdot 7 \\
76 \\
(56-101)\end{array}$ & $\begin{array}{l}22157 \\
122 \\
5 \cdot 4 \\
85 \\
(68-108)\end{array}$ & $\begin{array}{l}44159 \\
272 \\
6 \cdot 3 \\
100\end{array}$ & $\begin{array}{l}87563 \\
474 \\
5 \cdot 4\end{array}$ & $<0.0005$ \\
\hline $\begin{array}{l}\text { Mortality: } \\
\text { Cases } \\
\text { Rates } \\
\text { RR }{ }^{\circ}{ }^{\circ} \\
\left(95^{\circ}{ }_{0} \mathrm{CI}\right)\end{array}$ & $\begin{array}{l}10 \\
1 \cdot 3 \\
34 \\
(18-66)\end{array}$ & $\begin{array}{l}39 \\
2 \cdot 9 \\
78 \\
(54-112)\end{array}$ & $\begin{array}{l}71 \\
3 \cdot 3 \\
88 \\
(66-117)\end{array}$ & $\begin{array}{l}169 \\
3 \cdot 7 \\
100\end{array}$ & $\begin{array}{l}289 \\
3 \cdot 3\end{array}$ & $<0.005$ \\
\hline \multicolumn{7}{|c|}{ Ages 45-54 at entry } \\
\hline $\begin{array}{l}\text { Attack rate: } \\
\text { Cases } \\
\text { Rates } \\
\text { RR }^{\circ}{ }^{\circ} \\
\left(95^{\circ}{ }_{0} \mathrm{CI}\right)\end{array}$ & $\begin{array}{l}10 \\
2 \cdot 1 \\
33 \\
(17-64)\end{array}$ & $\begin{array}{l}38 \\
6 \cdot 3 \\
97 \\
(66-144)\end{array}$ & $\begin{array}{l}77 \\
6 \cdot 1 \\
94 \\
(69-128)\end{array}$ & $\begin{array}{l}125 \\
6 \cdot 5 \\
100\end{array}$ & $\begin{array}{l}250 \\
5 \cdot 9\end{array}$ & $<0.025$ \\
\hline $\begin{array}{l}\text { Mortality: } \\
\text { Cases } \\
\text { Rates } \\
\text { RR }{ }^{\circ} \\
\left(95^{\circ}{ }_{0}^{\circ} \mathrm{CI}\right) \\
\text { Total No of men }\end{array}$ & $\begin{array}{l}3 \\
0 \cdot 63 \\
24 \\
(7-78) \\
508\end{array}$ & $\begin{array}{l}20 \\
3 \cdot 3 \\
125 \\
(73-214) \\
776\end{array}$ & $\begin{array}{l}34 \\
2 \cdot 7 \\
101 \\
(65-158) \\
1216\end{array}$ & $\begin{array}{l}52 \\
2 \cdot 6 \\
100 \\
2052\end{array}$ & $\begin{array}{l}109 \\
2 \cdot 6 \\
4552\end{array}$ & $>0.05$ \\
\hline \multicolumn{7}{|c|}{ Ages 55-64 at entry } \\
\hline $\begin{array}{l}\text { Attack rate: } \\
\text { Cases } \\
\text { Rates } \\
\text { RR }{ }^{\circ} \\
\left(95^{\circ}{ }_{\circ}^{\circ} \mathrm{C}\right) \mathrm{I} \\
\text { Mortality: }\end{array}$ & $\begin{array}{l}8 \\
2 \cdot 3 \\
39 \\
(19-82)\end{array}$ & $\begin{array}{l}24 \\
3 \cdot 3 \\
56 \\
(36-88)\end{array}$ & $\begin{array}{l}45 \\
4 \cdot 5 \\
78 \\
(54-111)\end{array}$ & $\begin{array}{l}147 \\
5.9 \\
100\end{array}$ & $\begin{array}{l}224 \\
5 \cdot 0\end{array}$ & $<0.001$ \\
\hline $\begin{array}{l}\text { Cases } \\
\text { Rates } \\
\mathrm{RR}^{\circ}{ }^{\circ} \\
\left(95^{\circ} \mathrm{CI}\right) \\
\text { Total No of men }\end{array}$ & $\begin{array}{l}7 \\
2 \cdot 1 \\
45 \\
(20-98) \\
356\end{array}$ & $\begin{array}{l}19 \\
2 \cdot 6 \\
56 \\
(34-93) \\
920\end{array}$ & $\begin{array}{l}37 \\
3 \cdot 8 \\
82 \\
(55-121) \\
860\end{array}$ & $\begin{array}{l}117 \\
4 \cdot 6 \\
100 \\
2688\end{array}$ & $\begin{array}{l}180 \\
4 \cdot 0 \\
4824\end{array}$ & $<0.005$ \\
\hline \multicolumn{7}{|c|}{ Ages 45-64 at entry } \\
\hline $\begin{array}{l}\text { Cases } \\
\text { Rates } \\
\text { RR }^{\circ}{ }_{0} \\
\left(95^{\circ} \mathrm{CI}\right) \\
\text { In over } 4 \text { years follow up:* }\end{array}$ & $\begin{array}{l}11 \\
3 \cdot 3 \\
41 \\
(22-76)\end{array}$ & $\begin{array}{l}54 \\
6 \cdot 5 \\
81 \\
(56-119)\end{array}$ & $\begin{array}{l}52 \\
6 \cdot 9 \\
85 \\
(63-116)\end{array}$ & $\begin{array}{l}141 \\
8.0 \\
100\end{array}$ & $\begin{array}{l}158 \\
7 \cdot 1\end{array}$ & $<0.01$ \\
\hline $\begin{array}{l}\text { Cases } \\
\text { Rates } \\
\mathrm{RR}^{\circ}{ }^{\circ} \\
\left(95^{\circ}{ }_{0} \mathrm{CI}\right)\end{array}$ & $\begin{array}{l}7 \\
1 \cdot 5 \\
29 \\
(13-63)\end{array}$ & $\begin{array}{l}26 \\
3 \cdot 5 \\
69 \\
(45-107)\end{array}$ & $\begin{array}{l}59 \\
4 \cdot 5 \\
89 \\
(64-123)\end{array}$ & $\begin{array}{l}124 \\
5 \cdot 0 \\
100\end{array}$ & $\begin{array}{l}216 \\
4 \cdot 3\end{array}$ & $<0.001$ \\
\hline
\end{tabular}

^Mortality in groups 1-4 ranges from 1.9 to 3.7 per 1000 man-years at $0-4$ years of follow up and from 0.9 to 3.8 at over 4 years.

TOTALS OF PHYSICAL ACTIVITY IN LEISURE TIME We examined the possibility that high overall physical activity in leisure time, as such, would be protective against the heart disease. We did this by estimating the total physical activity in all the forms previously described but after excluding vigorous aerobic exercise. Energy expenditures were calculated in a similar way to the figures used in studies of the American men. ${ }^{9}$ The results after controlling for age were: for totals of $<2000 \mathrm{kcal} /$ week, 213 cases and a coronary attack rate of $5 \cdot 7$; for 2000-2999 $\mathrm{kcal} /$ week, 113 cases and a rate of $5 \cdot 2$; for $\geqslant$ $3000 \mathrm{kcal} / \mathrm{week}, 148$ cases and a rate of $5 \cdot 3 / 1000$ man-years. So for these data there was no gradient in coronary heart disease associated with total profiles of energy expenditure.

In group 4 coronary rates did not fall with increasing energy output. On the contrary: at energy expenditures of $<2000 \mathrm{kcal} /$ week the attack rate was 5.9; at 2000-2999 it was 6.5; and at $\geqslant 3000$ it was $7 \cdot 0 / 1000$ man-years. It may be added that group 4 rates were not affected by report of playing vigorous sports before entry in 1976.

EXERCISERS AND OTHER MEN

Table 5 examines the effect of selection for vigorous aerobic exercise in this homogeneous cohort, and some potential confounding factors, such as (A) family history and stature predispositions with plausibly a substantial genetic component; (B) expressed beliefs, attitudes, and health consciousness; (C) other health related behaviour; and (D) precursors of clinical coronary heart disease which may produce some circular double counting because of all the factors these are most likely also to be influenced by the effects of exercise.

It seems that those men taking vigorous aerobic exercise were at advantage in terms of coronary risk. For example, men in group 1 were less likely to have a family history of coronary heart disease and were more likely to have never smoked; and men in groups 1 and 2 were more likely to report a health conscious diet. The figures for totals of other physical activity in groups 1 and 2 may be pointing to a high overall energy output (with its attendant high intake) as a personality trait of vigorous exercisers. ${ }^{2021}$ It is instructive too that men in group 4, reporting none of the specific protective exercise, are particularly disadvantaged in terms of smoking, diet, weight gain (behavioural skills of today?), and in confidence about the possibility of personal control of future health - a marker for motives and the drive to exercise. ${ }^{2223}$ 
Table 5 Relative frequencies of some possible selective factors for vigorous aerobic exercise (VAE) in male executive grade civil servants

\begin{tabular}{|c|c|c|c|c|}
\hline \multirow[b]{2}{*}{ Personal characteristic ${ }^{\star}$} & \multicolumn{4}{|c|}{ Vigorous aerobic exercise } \\
\hline & $\begin{array}{l}\text { Group } 1 \\
\text { (frequent/intense) } \\
(n=216) \dagger \\
(\%)\end{array}$ & $\begin{array}{l}\text { Group } 2 \\
(\text { next lesser degree }) \\
(n=424) \\
(\%)\end{array}$ & $\begin{array}{l}\text { Group } 3 \\
\text { (residual, little) } \\
(n=519) \\
(\%)\end{array}$ & $\begin{array}{l}\text { Group } 4 \\
\text { (none) } \\
(n=1185) \\
(\%)\end{array}$ \\
\hline \multicolumn{5}{|l|}{ (A) } \\
\hline \multicolumn{5}{|l|}{$\begin{array}{l}\text { Parent(s) died prematurely CVD } \\
\text { Stature: }\end{array}$} \\
\hline $\begin{array}{l}\geqslant 5 \mathrm{ft} 11 \text { inch }(1.80 \mathrm{~m}) \\
\leqslant 5 \mathrm{ft} 6 \text { inch }(1.68 \mathrm{~m})\end{array}$ & $\begin{array}{l}31 \\
14\end{array}$ & $\begin{array}{l}29 \\
15\end{array}$ & $\begin{array}{l}27 \\
15\end{array}$ & $\begin{array}{l}24 \\
17\end{array}$ \\
\hline $\begin{array}{l}\text { Energy output: } \S \\
\geqslant 3000 \mathrm{kcal} \\
<2000 \mathrm{kcal}\end{array}$ & $\begin{array}{l}47 \\
33\end{array}$ & $\begin{array}{l}46 \\
27\end{array}$ & $\begin{array}{l}38 \\
32\end{array}$ & $\begin{array}{l}23 \\
55\end{array}$ \\
\hline \multicolumn{5}{|l|}{ (B) } \\
\hline $\begin{array}{l}\text { ill-health in the future" } \\
\text { "Takes sufficient care of health" } \\
\text { "Takes enough exercise to keep healthy" } \\
\text { (C) }\end{array}$ & $\begin{array}{l}69 \\
43 \\
68\end{array}$ & $\begin{array}{l}71 \\
32 \\
56\end{array}$ & $\begin{array}{l}62 \\
27 \\
45\end{array}$ & $\begin{array}{l}53 \\
28 \\
38\end{array}$ \\
\hline \multicolumn{5}{|l|}{ Cigarette smoking: } \\
\hline $\begin{array}{l}\text { Never } \\
\geqslant 20 \text { per day } \\
\text { Health conscious diet: } 9\end{array}$ & $\begin{array}{l}40 \\
11\end{array}$ & $\begin{array}{l}27 \\
12\end{array}$ & $\begin{array}{l}25 \\
16\end{array}$ & $\begin{array}{l}23 \\
21\end{array}$ \\
\hline $\begin{array}{l}3 \text { or } 4 \text { points } \\
\text { No points }\end{array}$ & $\begin{array}{l}29 \\
17\end{array}$ & $\begin{array}{l}30 \\
14\end{array}$ & $\begin{array}{l}18 \\
25\end{array}$ & $\begin{array}{l}16 \\
30\end{array}$ \\
\hline \multicolumn{5}{|l|}{ Weight in past year: $\star \star$} \\
\hline $\begin{array}{l}\text { Stable } \\
\text { Gaining } \\
\text { Losing } \\
\text { (D) } \\
\text { Body mass index:t+ }\end{array}$ & $\begin{array}{l}82 \\
8 \cdot 1 \\
9 \cdot 4\end{array}$ & $\begin{array}{l}78 \\
7 \cdot 8 \\
14\end{array}$ & $\begin{array}{l}80 \\
8 \cdot 0 \\
12\end{array}$ & $\begin{array}{l}75 \\
12 \\
12\end{array}$ \\
\hline $\begin{array}{l}\leqslant 24 \\
\geqslant 27\end{array}$ & $\begin{array}{l}44 \\
10\end{array}$ & $\begin{array}{l}42 \\
14\end{array}$ & $\begin{array}{l}39 \\
18\end{array}$ & $\begin{array}{l}32 \\
24\end{array}$ \\
\hline $\begin{array}{l}\text { Cardiovascular history: } \\
\text { High blood pressure } \\
\text { Diabetes } \\
\text { Questionnaire angina } \ddagger \ddagger \\
\text { "Subclinical" CVD\$ } \$\end{array}$ & $\begin{array}{l}4 \cdot 1 \\
1 \cdot 1 \\
1.9 \\
6 \cdot 5\end{array}$ & $\begin{array}{l}5 \cdot 9 \\
1 \cdot 2 \\
3 \cdot 4 \\
9 \cdot 6\end{array}$ & $\begin{array}{l}8 \cdot 0 \\
2 \cdot 3 \\
3 \cdot 4 \\
12\end{array}$ & $\begin{array}{c}9 \cdot 6 \\
1 \cdot 8 \\
3 \cdot 1 \\
13\end{array}$ \\
\hline 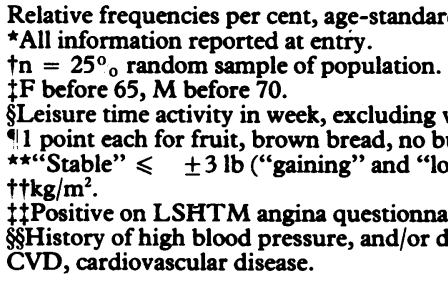 & $\begin{array}{l}\text { by direct method. } N \\
\text { us aerobic exercise.; } \\
\text { 'usually every day"; } \\
>3 \mathrm{lb} \text { ). } \\
\text { s, and/or positive or }\end{array}$ & $\begin{array}{l}-64 . \\
\text { brown bread exclusi } \\
\text { stionnaire. }\end{array}$ & & \\
\hline
\end{tabular}

Table 4 also shows that the main observation is at least as strong in the later years, up to 9.3, as in the earlier years of follow up, partially refuting an explanation by secondary selection: that is, that men who were taking less exercise at entry already had limiting subclinical (heart) disease.

MULTIPLE FACTORS OF CORONARY HEART DISEASE Table 6 shows the reported exercise groups, controlled for age and the main variables examined in table 5 . In general, the gradients of the heart disease with standard risk factors are much as would be expected: compare the rates in men with a bad family history and a good family history; in short men and tall men; in smokers and non-smokers. Trends over the exercise groups, however, are similar to those of table 4-whether or not the men are at an advantage in terms of other factors, with good family history or bad, tall or short, and so onlower coronary rates are evident in group 1 and to a lesser extent in group 2.

Multivariate analysis. Table 7 simultaneously "standardises" the exercise groups in each of the age bands for two, then three, then five of the other factors in a further attempt to allow for confounding of the main observation. This successive computation made little difference, however, to the overall picture of table 4-that is, the advantages of group 1 and of the older men in group 2 persisted-though the confidence intervals were widened. This emphasises the "independence" of vigorous aerobic exercise from classic risk factors.

\section{ALL CAUSES DEATH RATE}

Finally, it is necessary to know whether the reduction in coronary deaths was offset by deaths certified as other causes. This could arise from diagnostic and certification practices and/or excess deaths produced by vigorous aerobic exercise. There is no sign of this.

All deaths during the follow up were allotted to the four groups. Of the entrants aged 45-54, $3 \cdot 1 \%$ (139 deaths) died in 1976-86 from causes other than coronary disease, as did 5.6\% (278 deaths) of the entrants of 55-64. The risk of such death in the whole cohort of 45-64, standardised for age at entry and for cigarette smoking, was $3 \cdot 1 \%$ in group 1 compared with $4.9 \%$ in group 4 , the men reporting no vigorous aerobic exercise. For those men aged 55-64 the rate for smokers in group 2 was 8.7 compared with 9.0 in group 4 and for non-smokers it was 4.4 and 5.4 respectively. When non-coronary deaths were added to those from coronary heart disease, total death rates over the $9+$ years of follow up were lower in men with an exercise related reduction in coronary heart disease, and their survival through middle age and into old age greater than in other men. Detailed analysis 
Table 6 Vigorous aerobic exercise and other risk factors: attack rate from coronary heart disease (1976-86) in male executive grade civil servants (rates per 1000 man-years)

\begin{tabular}{|c|c|c|c|c|c|c|c|c|}
\hline \multirow[b]{3}{*}{ Risk factors* } & \multicolumn{8}{|c|}{ Vigorous aerobic exercise } \\
\hline & \multicolumn{2}{|c|}{$\begin{array}{l}\text { Group } 1 \\
\text { (frequent/intense) }\end{array}$} & \multicolumn{2}{|c|}{$\begin{array}{l}\text { Group } 2 \\
\text { (next lesser degree) }\end{array}$} & \multicolumn{2}{|c|}{$\begin{array}{l}\text { Group } 3 \\
\text { (residual, little) }\end{array}$} & \multicolumn{2}{|c|}{$\begin{array}{l}\text { Group } 4 \\
\text { (none) }\end{array}$} \\
\hline & $\overline{\text { Cases }}$ & Rates & Cases & Rates & Cases & Rates & Cases & Rate \\
\hline & \multicolumn{8}{|c|}{ Attack rate ages $45-64$} \\
\hline $\begin{array}{l}\text { Family history: } \\
\text { Parent(s) alive } \\
\text { Parent(s) died CVD }\end{array}$ & $\begin{array}{r}14 \\
4\end{array}$ & $\begin{array}{c}2 \cdot 0 \\
(3.6)\end{array}$ & $\begin{array}{l}44 \\
18\end{array}$ & $\begin{array}{l}4 \cdot 2 \\
6.8\end{array}$ & $\begin{array}{l}94 \\
28\end{array}$ & $\begin{array}{l}5 \cdot 1 \\
6 \cdot 5\end{array}$ & $\begin{array}{r}198 \\
74\end{array}$ & $\begin{array}{l}5.7 \\
8.8\end{array}$ \\
\hline $\begin{array}{l}\text { Stature: } \\
\quad \geqslant 5 \mathrm{ft} 11 \text { inch }(1.80 \mathrm{~m}) \\
5 \mathrm{ft} 9 \text { inch- } 5 \mathrm{ft} 10 \text { inch }(1.75-1.78 \mathrm{~m}) \\
5 \mathrm{ft} 7 \text { inch- } 5 \mathrm{ft} 8 \text { inch }(1.70-1.73 \mathrm{~m}) \\
\leqslant 5 \mathrm{ft} 6 \text { inch }(1.68 \mathrm{~m})\end{array}$ & $\begin{array}{l}3 \\
6 \\
5 \\
4\end{array}$ & $\begin{array}{l}(1 \cdot 1) \\
2 \cdot 6 \\
2 \cdot 2 \\
(4 \cdot 0)\end{array}$ & $\begin{array}{l}15 \\
16 \\
18 \\
13\end{array}$ & $\begin{array}{l}4 \cdot 2 \\
4 \cdot 2 \\
5 \cdot 0 \\
6 \cdot 4\end{array}$ & $\begin{array}{l}29 \\
30 \\
41 \\
22\end{array}$ & $\begin{array}{l}4 \cdot 7 \\
4 \cdot 7 \\
6 \cdot 5 \\
6 \cdot 7\end{array}$ & $\begin{array}{l}52 \\
74 \\
89 \\
56\end{array}$ & $\begin{array}{l}4.9 \\
6.0 \\
6.9 \\
7.8\end{array}$ \\
\hline $\begin{array}{l}\text { "Can do anything to prevent ill-health in the future": } \\
\text { Definitely } \\
\text { Perhaps/largely chance }\end{array}$ & $\begin{array}{l}9 \\
9\end{array}$ & $\begin{array}{l}1 \cdot 5 \\
3 \cdot 7\end{array}$ & $\begin{array}{l}48 \\
14\end{array}$ & $\begin{array}{l}4 \cdot 9 \\
4 \cdot 2\end{array}$ & $\begin{array}{l}67 \\
55\end{array}$ & $\begin{array}{l}4 \cdot 8 \\
6 \cdot 3\end{array}$ & $\begin{array}{l}150 \\
135\end{array}$ & $\begin{array}{l}5.9 \\
6 \cdot 7\end{array}$ \\
\hline $\begin{array}{l}\text { Cigarette smoking: } \\
\text { Never } \\
\text { Ex } \\
\text { Current }\end{array}$ & $\begin{array}{l}7 \\
6 \\
5\end{array}$ & $\begin{array}{l}2 \cdot 2 \\
1 \cdot 8 \\
2 \cdot 8\end{array}$ & $\begin{array}{l}11 \\
26 \\
25\end{array}$ & $\begin{array}{l}3 \cdot 2 \\
3.9 \\
8 \cdot 3\end{array}$ & $\begin{array}{l}27 \\
48 \\
47\end{array}$ & $\begin{array}{l}4 \cdot 5 \\
4 \cdot 7 \\
7 \cdot 1\end{array}$ & $\begin{array}{r}55 \\
88 \\
129\end{array}$ & $\begin{array}{l}5 \cdot 7 \\
4 \cdot 6 \\
8 \cdot 7\end{array}$ \\
\hline $\begin{array}{l}\text { Body mass index: } \\
\quad<24 \\
24-26.9 \\
\geqslant 27\end{array}$ & $\begin{array}{l}7 \\
9 \\
1\end{array}$ & $\begin{array}{c}1 \cdot 9 \\
2 \cdot 4 \\
(1 \cdot 3)\end{array}$ & $\begin{array}{r}19 \\
35 \\
8\end{array}$ & $\begin{array}{l}3.4 \\
6 \cdot 0 \\
4 \cdot 8\end{array}$ & $\begin{array}{l}40 \\
54 \\
27\end{array}$ & $\begin{array}{l}4 \cdot 3 \\
5 \cdot 7 \\
7 \cdot 1\end{array}$ & $\begin{array}{r}75 \\
119 \\
75\end{array}$ & $\begin{array}{l}5 \cdot 5 \\
6 \cdot 2 \\
7 \cdot 3\end{array}$ \\
\hline $\begin{array}{l}\text { "Subclinical" CVD: } \\
\text { Negative } \\
\text { Positive }\end{array}$ & $\begin{array}{r}14 \\
4\end{array}$ & $\begin{array}{c}1 \cdot 8 \\
(7 \cdot 5)\end{array}$ & $\begin{array}{r}54 \\
8\end{array}$ & $\begin{array}{l}4 \cdot 5 \\
6 \cdot 7\end{array}$ & $\begin{array}{l}92 \\
30\end{array}$ & $4 \cdot 5$ & $\begin{array}{r}185 \\
87\end{array}$ & $\begin{array}{l}4.9 \\
15\end{array}$ \\
\hline
\end{tabular}

^See tables 4 and 5 for description of groups and definitions.

of mortality in general will have to be based on larger numbers and so a longer follow up..$^{25} 26$

\section{Discussion}

There is considerable evidence that exercise protects the heart against ischaemic disease ${ }^{727}$ and it is now a central feature of national preventive campaigns such as the British "Look After Your Heart!".

Men engaging in the exercise identified as protective manifestly were a selected group. But tables 6 and 7 are the latest in a long line of analyses suggesting that it is the activity itself that protects, and that "self-selection" is not an adequate explanation of observed effects. ${ }^{3428-32}$ If selection bias is still an issue it will have to be resolved by other approaches, through biological markers perhaps or, in theory, a large randomised trial. Knowledge of selective factors is critical for understanding aetiology and in health promotion, but the practical message seems clear. Because nearly $30 \%$ of our older men were in groups 1 or 2, more than a (hypothetical) athletic minority may already be benefiting from adequate aerobic exercise in some sections of society.

Our participants were probably more healthy and fit than average because they are a working population and because we excluded men with a clinical history of coronary heart disease; they were more active too than the national population of their age and social class (2). ${ }^{11}$

Activities other than vigorous aerobic exercise werẹ not associated with benefit in coronary rates, nor did high totals of physical activity per se-whatever their other benefits undoubtedly are. ${ }^{7}$ Incidentally, though the term "vigorous" is used, vigorous enough on average for a training effect in such men is intended, and in the totality of exercise "moderately intense" might be a more appropriate term. This is particularly the case for the older cohort of 55-64 in group 2 who were observed for mortality up to 73 years of age and who showed a benefit associated with a lesser degree of the identified vigorous aerobic exercise but again not with any other form of exercise. Because major anatomical and physiological determinants of oxygen transport and physical working capacity decline with age, less intense exercise of the appropriate kind may be adequate to induce and maintain cardiorespiratory training. ${ }^{5-81934}$ By the same token, the minority of American men who derive some protective benefit from even more moderate aerobic exercise (corresponding here to non-vigorous sports and ordinary "normal" walking) may have been less healthy, active, and fit on average than our participants, and thus more able to derive some benefit from less intense exercise. These are testable propositions.

In general, significant protection against the heart disease was seen in the British men with less frequent vigorous sports than the current consensus advises. ${ }^{33}$ The duration of the episodes of sports and games could not be satifactorily studied.

\section{"HEAVY WORK"}

In the previous study this was inconsistently and rather weakly associated with protection but now fuller and more representative data show no association at all. Unlike typical occupational heavy work, recreational heavy work is liable to be periodic (seasonal digging) or occasional (those heavy building jobs); the number of men reporting some such work was surprisingly large. The activity itself entails discontinuous lifting and carrying, pushing and pulling of heavy objects, and gripping against resistance by small muscles: and static loads with excessive rises in blood pressure may therefore occur. ${ }^{7}$ This contrasts with the sustained, predominantly dynamic, rhythmic contraction of large skeletal muscles, as in swim- 
Table 7 Vigorous aerobic exercise (VAE) and other risk factors: attack rates and deaths from coronary heart disease (1976-86) in male executive grade civil servants (rates per 1000 man-years) after multivariate analysis/standardisation ${ }^{16}$

\begin{tabular}{|c|c|c|c|c|c|}
\hline \multirow[b]{2}{*}{ Standardisation } & \multicolumn{4}{|c|}{$V_{\text {igorous aerobic exercise }}^{\star}$} & \multirow[b]{2}{*}{$p$} \\
\hline & $\begin{array}{l}\text { Group } 1 \\
\text { (frequent/intense) }\end{array}$ & $\begin{array}{l}\text { Group } 2 \\
\text { (next lesser degree) }\end{array}$ & $\begin{array}{l}\text { Group } 3 \\
\text { (residual, little) }\end{array}$ & $\begin{array}{l}\text { Group } 4 \\
\text { (none) }\end{array}$ & \\
\hline \multicolumn{6}{|c|}{ Ages 45-54 attack rate } \\
\hline $\begin{array}{l}\text { Cases } \\
\text { Rates } \\
\text { Relative risks }\left({ }_{0}^{\circ}\right) \\
\left(95^{\circ} \mathrm{CI}\right) \\
\text { (II) For }(\mathrm{I}) \text { plus cigarette smoking: }\end{array}$ & $\begin{array}{l}10 \\
2 \cdot 2 \\
35 \\
(18-68)\end{array}$ & $\begin{array}{l}38 \\
6 \cdot 3 \\
98 \\
(66-145)\end{array}$ & $\begin{array}{l}77 \\
6 \cdot 1 \\
95 \\
(70-129)\end{array}$ & $\begin{array}{l}125 \\
6 \cdot 5 \\
100\end{array}$ & $<0.025$ \\
\hline $\begin{array}{l}\text { Cases } \\
\text { Rates } \\
\text { RR }^{\circ} \\
\text { (CI) } \\
\text { (III) For (I) and (II) plus body mass index and "subclinical" CVD: }\end{array}$ & $\begin{array}{l}10 \\
2 \cdot 4 \\
37 \\
(19-74)\end{array}$ & $\begin{array}{l}38 \\
6 \cdot 3 \\
100 \\
(66-149)\end{array}$ & $\begin{array}{l}77 \\
6 \cdot 3 \\
100 \\
(73-137)\end{array}$ & $\begin{array}{l}125 \\
6 \cdot 3 \\
100\end{array}$ & $>0.05$ \\
\hline $\begin{array}{l}\text { Cases } \\
\text { Rates } \\
\text { RR }^{\circ} \text { o } \\
(\mathbf{C I})\end{array}$ & $\begin{array}{l}10 \\
2 \cdot 2 \\
37 \\
(18-77)\end{array}$ & $\begin{array}{l}38 \\
7 \cdot 8 \\
131 \\
(81-211)\end{array}$ & $\begin{array}{l}76 \\
6 \cdot 5 \\
110 \\
(77-158)\end{array}$ & $\begin{array}{l}124 \\
5 \cdot 9 \\
100\end{array}$ & $>0.05$ \\
\hline \multicolumn{6}{|c|}{ Ages 45-54 mortality } \\
\hline $\begin{array}{l}\text { Cases } \\
\text { Rates } \\
\text { RR }^{\circ}{ }^{\circ} \\
\text { (CI) } \\
\text { (II) For (I) plus cigarette smoking: }\end{array}$ & $\begin{array}{l}3 \\
(0 \cdot 66) \\
25 \\
(8-81)\end{array}$ & $\begin{array}{l}20 \\
3 \cdot 3 \\
126 \\
(73-216)\end{array}$ & $\begin{array}{l}34 \\
2 \cdot 7 \\
102 \\
(65-159)\end{array}$ & $\begin{array}{l}52 \\
2 \cdot 6 \\
100\end{array}$ & $>0.05$ \\
\hline $\begin{array}{l}\text { Cases } \\
\text { Rates } \\
\text { RR "。 } \\
\text { (CI) } \\
\text { (II) For (I) and (II) plus body mass index and "subclinical" CVD: }\end{array}$ & $\begin{array}{l}3 \\
(0 \cdot 63) \\
24 \\
(7-80)\end{array}$ & $\begin{array}{l}20 \\
3 \cdot 4 \\
132 \\
(75-231)\end{array}$ & $\begin{array}{l}34 \\
2 \cdot 7 \\
106 \\
(67-168)\end{array}$ & $\begin{array}{l}52 \\
2 \cdot 6 \\
100\end{array}$ & $>0.05$ \\
\hline $\begin{array}{l}\text { Cases } \\
\text { Rates } \\
\mathbf{R R}^{\circ} \text { o } \\
(\mathrm{CI})^{\circ}\end{array}$ & $\begin{array}{l}3 \\
(0 \cdot 58) \\
25 \\
(7-93)\end{array}$ & $\begin{array}{l}20 \\
4 \cdot 5 \\
198 \\
(103-378)\end{array}$ & $\begin{array}{l}34 \\
3 \cdot 2 \\
141 \\
(83-240)\end{array}$ & $\begin{array}{l}52 \\
2 \cdot 3\end{array}$ & $>0.05$ \\
\hline \multirow{4}{*}{$\begin{array}{l}\text { (I) For age, family history, and stature: } \\
\text { Cases } \\
\text { Rates } \\
\text { RR \% } \\
\text { (CI) } \\
\text { (II) For (I) plus cigarette smoking: } \\
\text { Cases } \\
\text { Rates } \\
\text { RR \% } \\
\text { (CI) } \\
\text { (III) For (I) and (II) plus body mass index and "subclinical" CVD: } \\
\text { Cases } \\
\text { Rates } \\
\text { RR o } \\
\text { (CI) }\end{array}$} & \multicolumn{5}{|l|}{ Ages 55-64 attack rate } \\
\hline & $\begin{array}{l}8 \\
2 \cdot 4 \\
41 \\
(20-87)\end{array}$ & $\begin{array}{l}24 \\
3 \cdot 4 \\
57 \\
(36-90)\end{array}$ & $\begin{array}{l}45 \\
4 \cdot 5 \\
77 \\
(54-110)\end{array}$ & $\begin{array}{l}146 \\
5 \cdot 9 \\
100\end{array}$ & $<0.005$ \\
\hline & $\begin{array}{l}8 \\
2 \cdot 6 \\
44 \\
(21-93)\end{array}$ & $\begin{array}{l}24 \\
3 \cdot 5 \\
60 \\
(38-95)\end{array}$ & $\begin{array}{l}45 \\
4 \cdot 6 \\
78 \\
(54-131)\end{array}$ & $\begin{array}{l}146 \\
5 \cdot 8 \\
100\end{array}$ & $<0.005$ \\
\hline & $\begin{array}{l}7 \\
2 \cdot 4 \\
43 \\
(19-101) \\
\text { Ages 55-64 mortality }\end{array}$ & $\begin{array}{l}24 \\
3 \cdot 6 \\
64 \\
(39-108)\end{array}$ & $\begin{array}{l}45 \\
4 \cdot 8 \\
86 \\
(56-131)\end{array}$ & $\begin{array}{l}145 \\
5.6 \\
100\end{array}$ & $<0.025$ \\
\hline $\begin{array}{l}\text { Cases } \\
\text { Rates } \\
\text { RR ०o } \\
\text { (CI) } \\
\text { (II) For (I) plus cigarette smoking: }\end{array}$ & $\begin{array}{l}7 \\
2 \cdot 1 \\
46 \\
(21-100)\end{array}$ & $\begin{array}{l}19 \\
2 \cdot 6 \\
56 \\
(34-92)\end{array}$ & $\begin{array}{l}37 \\
3 \cdot 8 \\
80 \\
(55-117)\end{array}$ & $\begin{array}{l}117 \\
4 \cdot 7 \\
100\end{array}$ & $<0.005$ \\
\hline $\begin{array}{l}\text { Cases } \\
\text { Rates } \\
\text { RR \% } \\
\text { (CI) } \\
\text { (III) For (I) and (II) plus body mass index and "subclinical" CVD: }\end{array}$ & $\begin{array}{l}7 \\
2 \cdot 2 \\
49 \\
(22-108)\end{array}$ & $\begin{array}{l}19 \\
2 \cdot 8 \\
64 \\
(36-102)\end{array}$ & $\begin{array}{l}37 \\
3 \cdot 8 \\
86 \\
(55-123)\end{array}$ & $\begin{array}{l}117 \\
4 \cdot 6 \\
100\end{array}$ & $<0.01$ \\
\hline 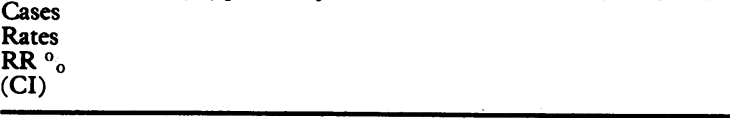 & $\begin{array}{l}6 \\
2 \cdot 3 \\
53 \\
(21-132)\end{array}$ & $\begin{array}{l}19 \\
2 \cdot 6 \\
59 \\
(34-105)\end{array}$ & $\begin{array}{l}37 \\
3 \cdot 9 \\
90 \\
(57-144)\end{array}$ & $\begin{array}{l}116 \\
4 \cdot 4 \\
100\end{array}$ & $<0.05$ \\
\hline
\end{tabular}

*See Tables 4 and 5 for description of groups and definitions.

ming, walking, cycling, distance running, rowing, and the like, that was found to be protective; and such activities are more likely to be performed with greater intensity "for exercise". It is possible, too, that the static element in the heavy work reported cancels out such benefit that any vigorous dynamic element in the activity might confer. ${ }^{35}$ Little is known of the energy costs and metabolic responses, long term haemodynamic function, training effects, and risk factor relations of major common physical activities in the real situations of everyday life.

MECHANISMS OF PROTECTION ${ }^{427} 28$

Exercise is viewed as a "general cause" of good health, ${ }^{2}$ and there is indeed evidence that all major processes of coronary heart disease are moderated by it. But it is not yet possible to assign weights in this apparent overdetermination.

Classic risk factors such as cigarette smoking, hypertension, or the body mass index were usually lower with exercise (table 5); and at the same time exercise counteracts them in some or large measure (as here in smoking, or overweight, table 6). Atherosclerosis may be reduced by the improved lipid profile, glucose/ insulin dynamics, ${ }^{36-38}$ and the lower blood pressure.

What is more interesting is that to be protective the exercise apparently has to be continuing and current: this suggests an effect on the acute phases of coronary heart disease- 
for example, fresh coronary thrombosis leading to acute obstruction, myocardial ischaemia, and arrhythmia. There is growing evidence that exercise can counter thrombosis by inhibiting clotting processes and platelet aggregation. ${ }^{79-42}$ In a national necropsy survey incidental major coronary obstruction was reported less often as the occupational physical activity of those who had died increased. ${ }^{43}$ The electrical stability of the heart may be enhanced, raising the threshold for arrhythmiafor example, by lowering catecholamine concentrations. ${ }^{44}$ The reduction in extrasystoles in men reporting vigorous aerobic exercise ${ }^{45}$ and the original observation that "sudden death" was low in the physically active workers ${ }^{1}$ may also be relevant.

It is encouraging (tables 4 and 7) that lower coronary rates are so evident in later middle and early old age. ${ }^{242739}$ After a lifetime's build up of the underlying atherosclerosis, protection against the acute precipitating phases of the heart disease is then the more realistic hope.

The protective exercise is that which trains for cardiorespiratory fitness; this is conventionally assessed by the maximal oxygen uptake. ${ }^{73334}$ An hypothesis in terms of "fitness" offers another explanation of the requirement for the exercise to be continuing. As shown in training/detraining experiments, ${ }^{4647}$ fitness achieved by exercise cannot be stored. Studies have favourably if variably related cardiorespiratory fitness to classic risk factors and to the heart disease. ${ }^{48-55}$

We may conjecture further. Stamina or endurance-the capacity for sustained aerobic exercise using a high proportion of the maximal oxygen uptake-whatever its level-is far more responsive to aerobic training than the actual maximum itself. ${ }^{56-58}$ Perhaps endurance fitness protects against coronary heart disease? Perhaps a reduction in the endurance fitness of the population is one of the consequences of the modern decline in physical activity, specifically of adequate aerobic exercise? An hypothesis in terms of endurance fitness would direct attention also to the optimal performance and adaptability, with training, of the heart itselfexemplified in the slower rate and increased stroke volume with given demands, and the greater electrical stability, myocardial perfusion, and, possibly, wall thickness. ${ }^{7834} 4759-62$ Such a proposition also underlines the need for practical non-invasive methods of assessing endurance fitness and training in the population $^{63}$ and is yet another plea for physiology and epidemiology to get together.

We were helped by the personnel and other central and local staffs of the Department of Health and Social Security and the Board of Inland Revenue; Mrs P Packman, the late Mrs J Martin, and Mrs W Gough (secretaries); Mrs D Cook and Mrs $M$ Fensom (patient coding and record-keeping); Mrs J MortonWilliams, Social and Community Planning Research (work on
the questionnaire) and the late Dr Sidney Chave who contributed greatly to earlier stages of the inquiry.

The investigation was funded by a special project grant of the Medical Research Council.

1 Morris JN, Heady JA, Raffle PAB, Roberts CG, Parks JW. Coronary heart disease and physical activity of work. Coronary heart disease and phy
Lancet 1953;ii:1053-7, 1111-20.

2 Morris JN. Uses of epidemiology. 3rd ed. London: Churchill
Livingstone, 1975 (reprinted 1983):142-67.

3 Morris JN, Chave SPW, Adam C, et al. Vigorous exercise in leisure-time and the incidence of coronary heart disease. Lancet 1973; i:333-9.

4 Morris JN, Everitt MG, Pollard R, Chave SPW, Semmence AM. Vigorous exercise in leisure-time: protection against coronary heart disease. Lancet 1980;ii:1207-10.

5 Haskell WL, Montoye HJ, Orenstein D. Physical activity and exercise to achieve health-related physical fitness components. Public Health Rep 1985;100:202-12.

6 Wenger HA, Bell GJ. The interaction of intensity, frequency and duration of exercise training in altering cardioand duration of exercise training in altering

7 Fentem PH, Bassey EJ, Turnbull N. The new case for exercise. London: Health Education Authority and Sports Council, 1988

8 McArdle WD, Katch FI, Katch VL. Exercise physiology. 2nd ed. Philadelphia: Lea and Febiger, 1986:347-70, 642-9.

9 Paffenbarger RS, Wing AL, Hyde RT. Physical activity as an index of heart attack risk in college alumni. $A m J$ Epidemiol 1978;108:161-75.

10 Paffenbarger RS, Hyde RT, Wing AL, Steinmetz CH. A natural history of athleticism and cardiovascular health. $J A M A$ 1984;252:491-5.

11 Office of Population Censuses and Surveys. General household survey, 1973, 1977. London: HMSO, 1976, 1979.

12 Moser CA, Kalton G. Survey methods in social investigation. 2nd ed. London: Heinemann, 1971.

13 Durnin JVA, Passmore R. Energy, work and leisure. London: Heinemann, 1967.

14 Wilson PWF, Paffenbarger RS, Morris JN, Havlik RJ. Assessment methods for physical activity and physical fitness in population studies: report of a NHLBI workshop. Am Heart J 1986;111:1177-92.

15 Prentice RL. A case-cohort design for epidemiological cohort studies and disease prevention trials. Biometrika 1986;73:1-11.

16 Breslow NE, Day NE. Statistical methods in cancer research. Vol II: The design and analysis of cohort studies. (IARC Scientific publications No. 82.) Lyon: IARC, 1987: $119-76$.

17 Borg G. Psychophysical basis of perceived exertion. Med Sci Sports Exerc 1982;14:371-81.

18 Carton RL, Rhodes EC. A critical review of the literature on ratings scales for perceived exertion. Sports Med 1985;2:198-222.

19 de Vries HA. Exercise intensity threshold for improvement of cardiovascular-respiratory function in older men. Geriatrics 1971;26:94-101.

20 Buss AH, Plomin R. A temperament theory of personality development. New York: Wiley, 1975:30-54, 149-54.

21 Morris JN, Marr JW, Clayton DG. Diet and heart: a postscript. Br Med J 1977;ii:1307-14.

22 Strecher VJ, De Vellis BM, Becker MH, Rosenstock IM The role of self-efficacy in achieving health behaviour change. Health Educ $Q$ 1986;13:73-92.

23 Wallston KA, Wallston BS. Health locus of control scales. In: Lefcourt HM, ed. Research with the locus of control construct. Vol. 1. New York: Academic Press, 1981: 189-243.

24 Rose GA, Blackburn H, Gillum RF, Prineas RJ. Cardiovascular survey methods. Geneva: WHO, 1982:162-3.

25 Chave SPW, Morris JN, Moss S, Semmence AM. Vigorous exercise and the death rate: a study of male civil servants. $J$ Epidemiol Community Health 1978;32:239-43.

26 Paffenbarger RS, Hyde RT, Wing AL, Hsieh C. Physical activity, all cause mortality and longevity of college alumni. N Engl J Med 1986;314:605-13;315:399-401, 595

27 Shephard RJ. Exercise in coronary heart disease. Sports Med 1986;3:26-49.

28 Powell KE, Thompson PD, Caspersen CJ, Kendrick JS. Physical activity and the incidence of coronary heart disease. Annu Rev Public Health 1987;8:253-87.

29 Heady JA, Morris JN, Kagan A, Raffle PAB. Coronary hear disease in London busmen: a progress report with particular reference to physique. Br J Prev Soc Med 1961;15:143-53.

30 Paffenbarger RS. Physical activity and fatal heart attack: protection or selection. In: Amsterdam EA, Wilmore JH, De Maria AN, eds. Exercise in cardiovascular health and disease. New York: Yorke, 1977:35-49.

31 Siscovick DS, La Porte RE, Newman JM. The disease specific benefits and risks of physical activity and exercise. Public Health 1985;100:180-8.

32 Salonen JT, Slater JS, Tuomilehto J, Rauramaa R. Leisuretime and occupational physical activity: risk of death from ischaemic heart disease. Am J Epidemiol 1988;127:87-94.

33 American College of Sports Medicine. Guidelines for exercise testing and prescription. 3rd ed. Philadelphia: Lea and Febiger, 1986:31-52.

34 Åstrand PO, Rodahl K. Textbook of work physiology. New York: McGraw-Hill, 1986:330-41, 412-85.

35 Ilmarinen J. Work and cardiovascular health. Ann Med 1989;21:209-14.

36 Wood PD, Williams PT, Haskell WL, et al. Physical activity and high density lipoproteins. In: Miller NE, Miller GJ, eds. Clinical and metabolic aspects of high density eds. Clinical and metabolic aspects of high
lipoproteins. Amsterdam: Elsevier, 1984:131-65.

37 Seals DR, Hagberg JM, Hurley BF, et al. Effects of endurance training on glucose tolerance and plasma lipids
levels in older men and women. JAMA 1984;252:645-9.

38 Thompson PD, Cullinare EM, Sady SP, et al. Modest changes in HDL liproprotein concentration and metabochanges in HDL liproprotein concentration and metabolism with prof 
39 Donahue RP, Abbott RD, Reed DM, Yano K. Physical activity and coronary heart disease in middle-aged and elderly men the Honolulu heart program. Am J Public Health 1988;78:683-5.

40 Andrews M, Carter C, O'Brodovich $\mathrm{H}$, Heigenhauser C Increases in factor VIII complex and fibrinolytic activity are dependent on exercise intensity. J Appl Physiol 1968;60:1917-22.

41 Watts EJ, Weir P. Reduced platelet aggregation in long distance runners. Lancet 1989;i:1013, 1398-9.

42 Davey Smith G, Marmot MG, Etherington M, O'Brien J. A work stress-fibrinogen pathway as a potential mechanism for employment grade differences in coronary heart disease rates. Abstracts, 2nd international conference on preventive cardiology, 1989, Washington DC.

43 Morris JN, Crawford MD. Coronary heart disease and physical activity of work: evidence of a national necrops survey. Br Med J 1958;ii: 1485-96.

44 Duncan JJ, Farr JE, Upton SJ, et al. The effects of aerobic exercise on plasma catecholamines and blood pressure in patients with mild essential hypertension. JAMA 1985;254:2609-13.

45 Epstein L, Miller GJ, Stitt FW, Morris JN. Vigorous exercise in leisure time, coronary risk-factors, and resting exercise in leisure time, coronary risk-factors, and resting Heart $J 1976 ; 38: 403-9$.

46 Saltin B, Blomquist G, Mitchell JH, Johnson RL, Wildenthal K, Chapman CB. Response to exercise after bed rest and after training. Circulation 1968;38(suppl VII): $1-77$.

47 Shapiro LM, Smith RG. Effect of training on left ventricular structure and function. An echocardiographic study. $\mathrm{Br}$ Heart $J$ 1983;50:534-9.

48 Gyntelberg F, Lauridsen L, Schubell K. Physical fitness and risk of myocardial infarction in Copenhagen males aged 40-59. Scand J Work Environ Health 1980;6:170-8.

49 Wilhelmsen L, Bjure J, Ekströmjodal B, et al. Nine years' follow-up of a maximal exercise test in a random sample of middle aged men. Cardiology 1981;68(suppl 2):1-8.

50 Peters RK, Cady LD Jr, Bischoff DP, Bernstein L, Pike MC. Physical fitness and subsequent myocardial infarcMC. Physical fitness and subsequent myocardial in
tion in healthy workers. $J A M A$ 1983;249:3052-6.

51 Lie H, Mundal R, Erikssen J. Coronary risk factors and incidence of coronary death in relation to physical fitness. Eur Heart $J$ 1985;6:147-57.

52 Ekelund L-G, Haskell WL, Johnson JL, et al. Physical fitness as a predictor of cardio-vascular mortality in asymptomatic north American men. $N$ Engl J Med 1988;319:1379-84.

53 Sobolski J, Kornitzer M, DeBacker G, et al. Protection against ischaemic heart disease in the Belgian physical fitness study. Am J Epidemiol 1987;125:601-10.

54 Slattery ML, Jacobs DR Jr. Physical fitness and cardiovascular disease mortality. The US railroad study. $A m$ Epidemiol 1988;127:571-80.

55 Blair SN, Kohl HW III, Paffenbarger RS, et al. Physical fitness and all-cause mortality. JAMA 1989;262: fitness and

56 Williams C, Nute MGL. Some physiological demands of a half marathon race on recreational runners. $B r J$ Sports Med 1983;17:152-61.

57 Gollnick PD, Saltin B. Hypothesis: significance of skeletal muscle oxidative enzyme enhancement with endurance training. Clin Physiol 1982;2:1-12.

58 Savard G, Keins B, Saltin B. Central cardiovascular factors as limits to endurance; with a note on the distinction between maximal oxygen uptake and endurance fitness. In: Macleod D, Maughan R, Nimmo R, Reilly T, Williams C, eds. Exercise benefits, limits and adaptations.

59 Leaf A. Chairman's panel statement. First International Conference on Nutrition and Fitness. Am J Clin Nutr 1989;49:936-7.

60 Tuxworth $B$. The fitness and physical activity of adolescents. Med J Aust 1988;148(Spec suppl):513-21.

61 Wolfe LA, Cunningham DA, Rechnitzer PA, Nichol PM. Effects of endurance training on left ventricular dimensions in healthy men. J Appl Physiol 1979;47: 207-12.

62 Washburn RA, Savage DD, Dearwater SR, et al. Echocardiographic left ventricular mass and physical activity. Am J Cardiol 1986;58:1248-53.

63 Fitness and Health Advisory Group of the Health Education Authority and The Sports Council. Activity and health 2000: prospectus of the national fitness survey. London 1988 .

\section{Appendix}

\section{STATISTICAL METHODS}

The data were analysed by relating the number of observed cases to the man-years denominators, which were calculated as follows. For men counted as cases, the observation time was taken as the time from entry into the study until the date of occurrence of the event. For those who were not counted as cases, the observation time was terminated either at the end of the follow up period (30 April 1986) or at death from another cause. The total man-years observation was estimated by multiplying the total observation time for non-cases by four (it was a $25 \%$ sample) and adding to this the total observation time for all cases. Partition of man-years observation between cells of tables followed established practice.

Inclusion, as cases, of men aged $>60$ who had non-fatal first events would have introduced a serious possibility of bias because of the incomplete follow up of morbidity after retirement. This was avoided by adopting a different case definition for men below the age of 60 . In men aged up to age 60 , an attack was defined as a first recognised occurrence of clinical disease, whether fatal or non-fatal. After that age attacks are defined as coronary deaths. While this definition leads to a rather strange relation between attack rate and age, the statistical method we used requires only that the effects of variables of interest upon the attack rate are approximately the same for different age groups. Counts of attacks and corresponding man-years observation were tabulated in the age bands 45-54, 55-59, 60-64, and $65+$, and standardised relative risk estimates, pooled over age, were calculated by Poisson modelling. ${ }^{16}$

Where standardised rates are shown, these were calculated by applying the fitted age specific rates for subgroups to the distribution of man-years observation by age for the entire cohort.

The validity of these assumptions was checked in two ways. Firstly, we examined the stability of relative risks by age and by stage of follow up; some of these analyses are reported in table 4. Second, all analyses were repeated (a) for first clinical episodes up to age 60 and (b) for mortality up to age 73. Although based upon many fewer cases, there was no suggestion that these analyses differed from the results of the composite analysis of all attacks as defined above. For analyses of mortality rates, the man-years observations were slightly greater than for attack rates. These have not been shown (since the discrepancy is negligible) but were used in the formal analyses.

The standard errors of the relative risk estimates obtained by Poisson modelling are rather optimistic, since no allowance is made for the fact that the man-years denominators were estimated from a sample of the cohort. Theoretical expressions for correct standard errors have been obtained only (a) for logistic regression analysis of the probability of disease occurrence at any time during follow up and (b) for individually matched analyses comparing each case with the corresponding "at risk" members of the sample cohort. ${ }^{15}$ The former is straightforward but the latter requires special software, which was not available at the time. Here an approximate approach was adopted; the standard errors obtained for Poisson modelling were inflated by the same factor as if simple logistic regression had been used. Similar corrections were applied to the significance tests. 